\title{
Metode Qiṣạs sebagai Upaya Meningkatkan Konsentrasi Belajar Siswa di Madrasah Ibtidaiyah Tarbiyatul Akhlaq Taman Sidoarjo
}

\author{
Moh. Ridhoi \\ STIT Maskumambang Gresik \\ Email: mohridhoimpdi@gmail.com
}

\author{
Abdul Halim \\ Universitas Airlangga Surabaya \\ Email: abdoelhaliem99@gmail.com
}

\begin{abstract}
Abstrak
Realitas berbicara bahwa di awal proses belajar mengajar, siswa dapat fokus mengikuti pelajaran di dalam kelas. Namun, ketika di tengah proses belajar mengajar, siswa merasa bosan, sehingga timbul keinginan untuk mengobrol dengan teman sebangku, atau bahkan siswa mengantuk dan tertidur di kelas. Karena itu, al-Qur'an menawarkan berbagai pendekatan dan metode dalam pendidikan, khususnya dalam menyampaikan materi pendidikan. Di antara beragam metode yang ada, metode qiṣaș al-Qur'an diterapkan dalam rangka mengembalikan konsentrasi siswa di MI Tarbiyatul Akhlaq Taman Sidoarjo. Penelitian ini bertujuan untuk mengetahui bagaimana metode qiṣās al-Qur'an sebagai upaya meningkatkan konsentrasi siswa di lembaga tersebut. Penulis menggunakan metode kualitatif agar mendapatkan sebuah data yang lebih mendalam dengan menggali informan penelitian. Hasil dari penelitian menunjukkan bahwa penerapan metode qișās al-Qur'an dapat dijadikan solusi untuk meningkatkan kemampuan menghafal siswa di MI Tarbiyatul Akhlaq Taman Sidoarjo. Ada dua tolak ukur yang dapat penulis temukan: pertama, kisah dalam al Qur'an mempunyai hubungan erat dengan permasalahan emosi melalui karakter yang ditampilkan oleh para tokoh dalam cerita, sehingga siswa menjadikannya role model dalam berprilaku. Kedua, bercerita dapat mengundang dan merangsang proses kognisi, sehingga siswa dapat berimajinasi, mengembangkan kesiapan dasar bagi perkembangan bahasa, serta dapat berfungsi untuk membangun hubungan akrab.
\end{abstract}

Kata Kunci: Metode Qiṣās, al-Qur'an, Konsentrasi Belajar, Aspek Kognitif 


\section{Pendahuluan}

Di era revolusi industri 4.0 ini, proses pendidikan agama Islam harus memiliki guru yang professional, kurikulum yang up to date, sarana dan prasarana yang mendukung. ${ }^{1} \mathrm{Hal}$ ini adalah tuntunan dalam rangka menghasilkan lulusan yang sesuai dengan kebutuhan dan harapan masyarakat luas. Guru merupakan sosok yang patut digugu, dan ditiru, serta pribadi yang pernuh rasa tanggung jawab dan bijaksana. ${ }^{2}$ Maka tidak salah jika sering kita dengar ungkapan "guru pahlawan tanpa tanda jasa".

Dalam dunia pendidikan agama Islam, guru tidak akan pernah terlepas dari proses pembelajaran, di mana pembelajaran yang dilaksanakan merupakan suatu rangkaian kegiatan yang terdiri dari beberapa komponen yang mempunyai keterkaitan antara satu dengan yang lainnya. Proses kegiatan pembelajaran di lembaga pendidikan Islam, merupakan salah satu solusi untuk terjadi interaksi antara guru dan peserta didik serta peserta didik dengan sesama peserta didik, di mana interaksi ini diharapkan dapat membantu peserta didik dalam mengembangkan potensi dirinya, baik dalam hal spiritual, maupun sosial. Proses interaksi tersebut sangat dibutuhkan peserta didik, selain agar mereka terhindar dari interaksi negatif ${ }^{3}$, juga agar peserta didik mampu meningkatkan potensi dirinya dalam bermuamalah kepada Allah SWT, bermuamalah kepada dirinya sendiri, dan bermuamalah kepada orang lain (masyarakat). ${ }^{4}$

Banyaknya metode pendidikan yang ditawarkan para ahli sebagaimana dijumpai dalam buku-buku kependidikan adalah lebih merupakan usaha untuk mempermudah pemahaman anak atas materi pelajaran. Dalam al-Qur'an, metode pendidikan harus bertolak dari pandangan yang tepat terhadap manusia, yang dapat dididik melalui

${ }^{1}$ Alfian Helmi, "Kinerja Guru Dalam Meningkatkan Prestasi Siswa Pada Smp Negeri 2 Babahrot Aceh Barat Daya", Jurnal Admistrasi Pendidikan, Vol.3, No.1, (2015).

2 Muhammad Rapi, "Sertitikasi Guru, Harapan dan Tantangan terhadap Guru”, Jurnal Harmoni, Vol.2, No.1 (2012).

${ }^{3}$ Lihat, Zaini Tamin AR dan Subaidi, "Implementasi Segregasi Kelas Berbasis Gender dalam Menaggulangi Interaksi Negatif Siswa di SMP Al-Falah Ketintang Surabaya", Al Hikmah: Jurnal Studi Keislaman, Vol. 9, No. 1 (2019).

4 I Ketut Sudarsana, "Pemikiran Tokoh Pendidikan dalam Buku Lifelong Learning: Policies, Practices, And Programs (Perspektif Peningkatan Mutu Pendidikan di Indonesia)", Jurnal Penjaminan Mutu, Vol.2, No.2, (2016). 
pendekatan jasmani, jiwa dan akal pikiran. ${ }^{5}$ Karena itu, al-Qur'an menawarkan berbagai pendekatan dan metode dalam pendidikan, yakni dalam menyampaikan materi pendidikan. Metode tersebut yaitu metode teladan, metode kisah atau cerita, metode nasihat, metode pembiasaan, metode hukuman dan ganjaran, metode ceramah (khutbah) dan metode diskusi. Dan yang akan dibahas lebih lanjut dalam bahasan karya ilmiyah ini adalah metode qiṣass (kisah). Metode qișās al-Qur'an adalah suatu cara mengajar di mana siswa melaksanakan kegiatan-kegiatan pemahaman, agar siswa memiliki penyerapan atau membuat kesimpulan dari apa yang dipelajari. ${ }^{6}$

Dalam mendidik anak diperlukan suatu metode yang sesuai. Dalam hal ini guru sebelum menggunakan metode harus benar-benar mempertimbangkan berbagai hal yaitu baik materi, metode maupun tujuan pendidikan Islam. Sehingga tujuan pendidikan Islam dapat terwujud dengan baik. Metode kisah sebagai salah satu metode pilihan yang digunakan dalam proses pendidikan anak dalam Islam dengan harapan dapat untuk menyampaikan materi, sesuai dengan kemampuan dan perkembangan jiwa anak, sehingga dapat dicapai suatu tujuan yang dikehendaki tersebut. Juga sebagai sarana untuk memperoleh suatu ketangkasan,ketepatan, kesempatan, dan keterampilan". ${ }^{7}$

Metode qișās al-Qur'an disebut juga metode pembiasaan; suatu kegiatan melakukan hal yang sama dengan tujuan memperkuat asosiasi atau penyempurnaan keterampilan supaya permanen. ${ }^{8}$ Kemampuan adalah kesanggupan / kecakapan untuk melakukan kinerja tertentu. Sedangkan menghafal adalah sebuah usaha yang aktif agar dapat memasukkan informasi ke dalam otak, sedangkan mengingat adalah sebuah upaya aktif untuk mengeluarkan informasi dari dalam otak. Jika kisah, objek tersebut dimasukkan dalam memori sedangkan mengingat, objek akan diambil untuk dikeluarkan".Kemampuan memhami dapat diartikan sebagai kemampuan memindahkan bahan bacaan ke dalam ingatan, menyimpan dalam memori, dan pengungkapan kembali pokok bahasan yang ada dalam memori”.

Jadi, penerapan metode qiṣās al-Qur'an untuk meningkatkan konsentrasi siswa di MI Tarbiyatul Akhlaq Taman Sidoarjo adalah suatu cara mengajar yang dilakukan oleh guru terhadap siswa dengan

5 Abuddin Nata, Filsafat Pendidikan Islam (Jakarta: Logos Wacana Ilmu, 1997), 94.

${ }^{6}$ Roestiyah, Strategi Belajar Mengajar (Jakarta: Bina Aksara, 1985), 125.

${ }^{7}$ Sa'dullah, Cara Cepat Menghafal Alquran (Jakarta: Gema Insani, 2008), 49

${ }^{8}$ Mahfud Shalahuddin, Metodologi Pengajaran Agama (Surabaya: Bina Ilmu, 1987), 100 
melakukan kegiatan-kegiatan yang sama, berulang-ulang secara sungguhsungguh untuk meningkatkan kesanggupan dalam memasukkan informasi / bahan bacaan ke dalam pikiran / otak agar selalu ingat dan bisa mengambil kesimpulan.

\section{Qișās dalam al-Qur'an}

Kata "kisah" secara etimologis (bahasa) berasal dari bahasa arab, yaitu berasal dari kata لقص lyang berarti mengikuti jejak, seperti disebutkan sebuah kalimat أَثر هقصصة saya mengikuti jejaknya. ${ }^{9}$ Kata atau مصص المثبعة/لاخبار (berita yang berarti berurutan), seperti disebutkan dalam firman Allah:

Artinya: "sesungguhnya pada kisah-kisah mereka itu terdapat pengajaran bagi orang-orang yang berakal" (Q.S. Yusuf: 111)

Dari segi terminologis (istilah), kata kisah berarti berita-berita mengenai permasalahan dalam masa-masa yang saling berturut-turut. ${ }^{10}$ Kisah berasal dari kata al-qashshu yang berarti mencari atau mengikuti jejak. Dikatakan, "qashashtu atsarahu" artinya, "saya mengikuti atau mencari jejaknya." Kata al qashsash adalah bentuk masdar. Qashash AlQur'an berisikann tentang hal ihwal umat yang telah lalu, nubuwat (kenabian) yang terdahulu dan peristiwa-peristiwa yang telah terjadi. ${ }^{11}$

Kata Qashashul berasal dari bahas Arab yang merupakan bentuk jamak dari kata Qiṣass yang berarti tatabbu' al-atsar (napak tilas/ mengulang kembali masa lalu). Qișās menurut Muhammad Ismail Ibrahim berarti hikayat (dalam bentuk) prosa yang panjang. ${ }^{12 .}$ Sedangkan menurut Manna Khalil al-Qattan "qashashtu atsarahu” berarti "kisah ialah menelusuri jejak" 13 Menurut perspektif al-Qur'an, Allah swt. mengungkapkan diriNya melalui peristiwa-peristwa, namun wahyuNya menggunakan tema-tema yang sudah terkenal dan dinyatakan kembali sampai orang-orang beriman meresapinya ${ }^{14}$ Al-Qur'an banyak

${ }^{9}$ Muhammad Warson Munawwir, Kamus Al Munawwir (Yogyakarta: UPBIK Pondok Pesantren Krapyak, 1984), 1243.

10 Yunahar Ilyas, Kuliah Ulumul Quran (Yogyakarta: Itqan Publishing, 2013),228.

${ }^{11}$ Manna' Khalil al-Qaththan, Mahabis fi Ulum al-Qur'an (Mansyurat al-Asr alHadis, 1973), 386-387.

12 Muhammad Ismail Ibrahim, Mu'jam al-Alfazh waAlam al-Qur'anniyat (Dar al-Fikr-al'Arabi,1969),140.

${ }^{13}$ Ibid., 305.

${ }^{14}$ Hasan Basri, Horizon al Qur'an (Jakarta: Balai Kajian Tafsir al Qur'an Pase, 2002), 80 
mengandung keterangan tentang kejadian pada masa lalu, sejarah bangsabangsa, keadaan negeri-negeri dan peninggalan atau jejak setiap umat.

Berdasarkan pengertian di atas, maka dapat dikatakan, bahwa pada kisah-kisah yang dimuat dalam al-Qur'an semuanya cerita yang benarbenar terjadi, tidak ada cerita fiksi, khayal, apalagi dongeng. Jadi bukan seperti tuduhan sebagian orientalis bahwa al Qur'an ada yang tidak cocok dengan fakta sejarah. ${ }^{15}$ Qisās al-Qur'an ialah khabar-khabar dari alQur'an tentang keadaan umat yang telah lalu dan kenabian masa dahulu, peristiwa-peristiwa yang telah terjadi, sejarah bangsa-bangsa, keadaan negeri-negeri serta menerangkan bekasan-bekasan dari kaum kala itu. Dan sesungguhnya al-Qur'an banyak memuat peristiwa-peristiwa masa lalu, sejarah umat-umat terdahulu, negara, perkampungan dan mengisahkan setip kaum dengan cara shuratan nathiqah (artinya seolaholah pembaca kisah tersebut menjadi pelaku sendiri yang menyaksikan peristiwa itu).

Di dalam al Qur'an, banyak sekali kisah-kisah yang dapat dijadikan materi sekaligus metode dalam pembelajaran. Surat Yusuf misalnya. Surat Yusuf adalah surat ke-12 dalam al-Qur'an. Di dalam surat ini menceritakan kisah tentang 12 bersaudara keturunan Ya'kub. Surat ini terdiri atas 111 ayat 1996 kalimat dan 7176 huruf. ${ }^{16}$ Surat ini termasuk golongan surat-surat Makkiyyah. Yusuf adalah satu-satunya nama dari surat ini. Ia dikenal sejak masa Nabi Muhammad Saw. Penamaan itu sejalan juga dengan kandungannya yang menguraikan kisah Nabi Yusuf as. Berbeda dengan banyak nabi yang lain, kisah beliau hanya disebut dalam surat ini. Nama beliau disebut dalam surat al-An'am dan surat alMu'min (Ghafir). ${ }^{17}$

Surat Yusuf turun di Mekah sebelum Nabi Saw. berhijrah ke Madrasah Diniyahah. Situasi dakwah ketika itu serupa dengan situasi turunnya surat Yunus, yakni sangat kritis, khususnya setelah peristiwa Isra' dan Mi'raj di mana sekian banyak yang meragukan pengalaman Nabi Saw. itu; bahkan sebagian yang lemah imannya menjadi murtad. Di sisi lain jiwa Nabi Muhammad Saw. sedang diliputi oleh kesedihan, karena istri beliau Sayyidah Khadijah ra. dan paman beliau Abu Thalib baru saja wafat. Nah, dalam situasi semacam itulah turun surat ini untuk menguatkan hati Nabi Saw. Ibnu Katsir al Hafidz, menerangkan bahwa

\footnotetext{
${ }^{15}$ Muhammad al Khidir Husain, Balogat al Qur'an (Ali al Rida al Tunisi, 1971), 104.

16 Nawawi, Marah Labid li Kasyfi Ma'na Qur'anin Majid (Semarang: Taha Putra, tt), 397.

${ }^{17}$ Quraish Shihab, Tafsir al-Mishbah; Pesan, Kesan dan Keserasian al-Quran (Jakarta:Lentera Hati, 2000), 375.
} 
segolongan orang Yahudi masuk agama Islam sesudah mereka mendengar cerita Yusuf a.s. ini, karena adanya kesesuaian dengan ceritacerita yang mereka ketahui. ${ }^{18}$. Surat ini dinamakan surat Yusuf adalah karena titik berat dari isinya mengenai riwayat Nabi Yusuf a.s. Riwayat tersebut salah satu di antara cerita-cerita ghaib yang diwahyukan kepada Nabi Muhammad s.a.w. sebagai mukjizat bagi beliau, sedang beliau sebelum diturunkan surat ini tidak mengetahuinya. Dari cerita Yusuf a.s. ini, Nabi Muhammad s.a.w. mengambil pelajaran-pelajaran yang banyak dan merupakan penghibur terhadap beliau dalam menjalankan tugasnya.

Yusuf adalah putra Ya'kub ibnu Ishaq ibnu Ibrahim as. Ibunya adalah Rahil, salah seorang dari tiga istri Nabi Ya'kub as. Ibunya meninggal ketika adiknya (Benyamin) dilahirkan, sehingga ayahnya mencurahkan kasih sayang kepada keduanya melebihi kasih sayang kepada kakak-kakaknya.

Surat Yusuf ini seluruh isinya berkisar pada cerita Nabi Yusuf a.s. dan saudara-saudaranya beserta orang tua mereka. Cara penuturan kisah Nabi Yusuf ini kepada Nabi Muhammad s.a.w. berbeda dengan kisahkisah nabi-nabi yang lain, yaitu kisah Nabi Yusuf a.s. ini khusus diceritakan dalam satu surat sedang kisah-kisah nabi-nabi yang lain disebutkan dalam beberapa surat. Isi dari kisah Nabi Yusuf a.s. ini berlainan pula dengan kisah-kisah nabi-nabi yang lain. Dalam kisah nabinabi yang lain Allah menitik beratkan kepada tantangan yang bermacammacam dari kaum mereka, kemudian mengakhiri kisah itu dengan kemusnahan para penantang para nabi itu. Didalam kisah Nabi Yusuf a.s ini, Allah s.w.t. menonjolkan akibat yang baik daripada kesabaran, dan bahwa kesenangan itu datangnya sesudah penderitaan. Allah menguji Nabi Ya'qub a.s. dengan kehilangan puteranya Yusuf a.s. dan penglihatannya, dan menguji ketabahan dan kesabaran Yusuf a.s. dengan dipisahkan dari ibu bapanya, dibuang ke dalam sumur, dan diperdagangkan sebagai budak. Kemudian Allah s.w.t menguji imannya dengan godaan wanita cantik lagi bangsawan dan akhirnya dimasukkan kedalam penjara. Kemudian Allah s.w.t. melepaskan Yusuf a.s. dan ayahnya dari segala penderitaan dan cobaan itu; menghimpunkan mereka kembali; mangembalikan penglihatan Ya'qub a.s. dan menghidupkan lagi cinta kasih antara mereka dengan Yusuf a.s.

Yang menjadi inti surat Yusuf ini terdapat pada ayat 3.

نحن نقص عليك احسن القصص بما اوحينا اليك هذ القران وان كنت من قبله لمن الغفلين

Artinya: "Kami menceritakan kepadamu kisah yang paling baik dengan mewahyukan Al Quran ini kepadamu, dan sesungguhnya kamu sebelum

${ }^{18}$ Ibnu Katsir al Hafidz, Tafsir al-Qur'an al-'Adzim (Mesir: Dar al-Hadits, 2003), 580 .

El-Banat Vol. 9. No.2 (2019) 267 
(Kami mewahyukan) nya adalah termasuk orang-orang yang belum mengetahui."

Kini al-Qur'an mengajak kita menuju kepada kisah yang di wahyukan ini. Allah Swt. Bagaikan berfirman, "kami tahu, masyarakat Arab yang engkau temui, wahai Muhammad, termasuk sahabatsahabatmu, bermohon kiranya engkau mengisahkan kepada mereka suatu kisah. Orang-orang Yahudi pun ingin mendengarnya. Karena itu, kami kini dan juga di masa yang akan datang akan menceritakan kepadamu kisah untuk memenuhi peremintaan mereka dan juga untuk menguatkan hati dan agar mereka menarik pelajaran. Kisah ini adalah kisah yang terbaik gaya kandungan dan tujuannya. Itu Kami lakukan dengan mewahyukan kepadamu al-Qur'an ini, dan sesungguhnya engkau sebelumnya yakni sebelum Kami mewahyukan sungguh termasuk kelompok orang-orang yang tidak mengetahui. Betapa engkau wahai Muhammad bahkan betapa kamu semua mengetahui, padahal kamu adalah masyarakat yang tidak pandai membaca. Kalaupun pandai, peristiwa yang dikisahkan ini sudah terlalu jauh masanya, sehingga rincian yang diketahui oleh siapapun sungguh banyak yang keliru dan tidak sesuai dengan kenyataan. ${ }^{19}$

( القصص (قصة) qishsah/kisah. Ia terambil dari kata (قصن) qashsa yang pada mulanya berarti mengikuti jejak. Kisah adalah upaya mengikuti jejak peristiwa yang benar-benar terjadi atau Imajinatif, sesuai dengan urutan kejadiannya dan dengan jalan menceritakannya satu episode, atau episode demi episode. Kata al-Ghafilin terambil dari kata (غلغافلين) ghafala yang makna dasarnya berkisar pada ketertutupan. Dari sini, sampul yang berfungsi menutup sesuatu di namai (غلاف) ghilaf, tanah yang tidak dikenal karena tanpa tanda-tanda dinamai (غلف) ghulf dan karena ketiadaan tanda itulah maka orang tidak mengetahuinya. Kata (غافل) ghaafil biasa juga diartikan lengah, yang tidak mengetahui bukan karena kepicikan akal, tetapi karena kurangnya perhatian.20

Tujuan utama surat ini adalah untuk membuktikan bahwa kitab suci al-Qur'an benar-benar adalah penjelasan menyangkut segala sesuatu yang mengantar kepada petunjuk, berdasar pengetahuan dan kekuasaan Allah Swt. secara menyeluruh-baik terhadap yang nyata maupun yang ghaib. Kisah Nabi Yusuf ini merupakan salah satu di antara cerita-cerita ghaib yang diwahyukan kepada Nabi Muhammad s.a.w. sebagai mukjizat

\footnotetext{
${ }^{19}$ Shihab, Tafsir al-Mishbah, 384

${ }^{20}$ Ibid., 384-385.
} 
bagi beliau, sedang beliau sebelum diturunkan surat ini tidak mengetahuinya.

ذالك من انباء الغيب نوحيه اليك وما كنت لديهم إذ اجمعو ا امر هم وهم يمكرون

Artinya: Demikian itu (adalah) di antara berita-berita yang ghaib yang Kami wahyukan kepadamu (Muhammad); padahal kamu tidak berada pada sisi mereka, ketika mereka memutuskan rencananya (untuk memasukkan Yusuf ke dalam sumur) dan mereka sedang mengatur tipu daya.

"Maka tatkala mereka membawanya dan sepakat memasukkannya ke dasar sumur (lalu mereka masukkan dia), dan (di waktu Dia sudah dalam sumur) Kami wahyukan kepada Yusuf: "Sesungguhnya kamu akan menceritakan kepada mereka perbuatan mereka ini, sedang mereka tiada ingat lagi."(15)

Rupanya desakan anak-anaknya dapat meyakinkan nabi Ya'qub. Nabi Ya'qub mengizinkan mereka membawanya lalu tatkala mereka membawanya. Bahkan, munurut Al-Qurthubi, sepanjang mata Ya'qub memandang, mereka menggendongnya menuju tempat penggembalaan untuk bermain dan bersuka ria. Dalam perjalanan itu sekali lagi mereka sepakat memasukkannya kedalam sumur. Akhirnya mereka memasukkannya. Dan sewaktu dian berada dalam sumur, kami wahyukan yakni kami ilhamkan kepadanya yakni kepada Yusuf sehingga hatinya tidak risau mengalami apa yang dihadapinya, "Hai Yusuf, jangan khawatir! Engkau aka selamat. Ini adalah tangga menuju kemuliaan, walau terlihat bagimu senagai kesulitan. Dan suatu ketika pasti engkau akan menceritakan kepada mereka perbuatan mereka ini, sedang mereka tidak sadar yakni tidak ingat lagi atau tidak mengetahui bahwa engkau adalah Yusuf, karena masa yang telah berlalu demikian panjang dan mereka pun mendugamu telah wafat."

Huruf $b a$ ' pada kata bihi pada firman-Nya dzahabu bihi mengandung makna keberdempetan (menempel) atau apa yang diistilahkan dalam kaidah bahasa arab lil-ilshaq. Hal ini, jika enggan dipahami dalam arti menggendong atau meletakkannya dipnggung mereka maka paling tidak kata tersebut menggambarkan bahwa mereka begitu mendekat dan bergandengan tangan dengan Yusuf. Kata dan yang mendahului awhaina ada yang memahaminya sekedar sebagai penguat yang biasa juga diistilah dengan $z a^{\prime}$ idah. ${ }^{21}$ Dan dengan demikian, kalimat kami wahyukan kepadanya merupakan penjelasan tentang apa yang terjadi ketika mereka membawa Yusuf ke tempat yang mereka tuju.

${ }^{21}$ Nasruddi Baidan, Wawasan Baru Ilmu Tafsir (Yogyakarta: Pustaka Pelajar, 2005), 230. 
"Kemudian mereka datang kepada ayah mereka di sore hari sambil menangis.(16) Mereka berkata: "Wahai ayah Kami, Sesungguhnya Kami pergi berlomba-lomba dan Kami tinggalkan Yusuf di dekat barang-barang Kami, lalu Dia dimakan serigala; dan kamu sekali-kali tidak akan percaya kepada Kami, Sekalipun Kami adalah orang-orang yang benar."(17)

Mereka datang membawa baju gamisnya (yang berlumuran) dengan darah palsu. Ya'qub berkata: "Sebenarnya dirimu sendirilah yang memandang baik perbuatan (yang buruk) itu; Maka kesabaran yang baik Itulah (kesabaranku). dan Allah sajalah yang dimohon pertolongan-Nya terhadap apa yang kamu ceritakan." Tercapai sudah maksud mereka melempar Yusuf ke dalam sumur. Setelah selesainya peristiwa yang menyedihkan itu, cukup lama mereka menunggu, karena enggan kembali di siang atau sore hari dan khawatir jangansampai ayah mereka melihat dengan jelas pada air muka mereka. ${ }^{22}$

Mereka datang kepada ayah mereka di malam hari saat gelap gulita tiba, sesaat setelah hiangnya mega meraha, sisa-sisa cahaya matahari setelah tenggelamnya dan mereka datang kepada ayah mereka sambil berpura-pura sedih dan menangis. Sang ayah bertanya, "apa yang terjadi?" apakah kambing diterkam domba?, belum lagi mereka menjawab sang ayah sadar bahwa Yusuf tidakbersama mereka. Dia bertanya "Mana Yusuf? Nah ketika itu;lah mereka berkata, "wahai ayah kami, sesungguhnya kami pergi berlomba -memanah atau menunggang kuda, atau besar kemungkinan lomba lari- dan kami tinggalkan saudara kami Yusuf didekat barang-barang kami agar dia menjaganya, lalu ketika kami sedikit jauh dari tempat Yusuf menunggu muncul serigala menerkamnya. Kami tak sempat menyelamatkan Yusuf dan dia dimakan habis oleh serigala itu. Kami menyampaikan hal ini kepadamu dengan rasa sedih, dan kami tahu, sekali-kali engkau tidak akan percaya kepada kami tentang apa yang kami sampaikan ini sekalipun kami adalah orangorang yang benar. Ini karena kami menyadari besarnya musibah yang menimpa ini. Namun demikian, walaupun kami tahu bahwa engkau tidak akan mempercayai kami, kami harus tetap menyampaikannya kepadamu, karena itulah keadaan yang sebenarnya."

Dan dalam upaya mereka lebih meyakinkan kebenaran apa yang mereka sampaikan itu, mereka datang membawa bajunya Yusuf yang berlumuran dengan darah palsu yang mereka nyatakan sebagai bekasbekas darah Yusuf, padahal itu adalah darah seekor binatang yang mereka sembelih lalu mereka lumurkan baju Yusuf dengan darah binatang itu. Hati Nabi Ya'qub tidak percaya. Tanda-tanda kebohongan merekapun

${ }^{22}$ Baidan, Wawasan Baru Ilmu Tafsir, 230. 
nampak olehnya. Perasaan dan firasat orang tua yang nabi itu pun berkata "tidak". Karena itu, dia berkata, "Kenyataan yang terjadi bukan seperti apa yang kalian sampaikan. Bagaimana mungkin dia diterkam serigala sedang pakaianny atidak koyak? Atau apakah dia seperti kalian membuka pakaiannya untuk bermain? Jika demikian, mengapa pakaian ini berdarah? Atau apakah dia tidak membukanya, tetapi serigala itu tidak mengoyaknya? Sungguh baik serigala itu jika demikian! Sebenarnya diri kamu telah memperindah bagi kamu satu perbuatan terhadap Yusuf. Aku tidak tahu persis apa yang kalian perbuat, tetapi pasti itu adalah sesuatu yang buruk maka kesabaran yang baik itulah kesabaranku. Aku tidak akan mengadu kecuali kepada-Nya sambil menerima ketetapan-Nya. Dan Allah sajalah yang dimohon pertolongan-Nya tentang apa yang kamu ceritakan bahwa Yusuf dimakan serigala. Aku berserah diri kepada Allah, semoga Dia yang Maha Kuasa itu membantu aku berkenaan apa yang disampaikan anak-anakku serta menampakkan kenyataannya.

Al-Qur'an tidak menceritakan kejadian dan peristiwa secara berurutan (kronologis) dan memaparkan kisah-kisah itu secara panjang lebar. Tetapi terkadang berbagai kisah disebutkan berulang-ulang dibeberapa tempat, ada pula beberapa kisah disebutkan al-Qur;an dalam bentuk yang berbeda, disatu tempat ada bagian yang di dahulukan dan ditempat lain diakhirkan. Kadang-kadang pula disajikan secara ringkas dan kadang secara panjang lebar. Hal tersebut menimbulkan perdebatan di antara kalangan orang yang meyakini dan orang-orang yang meragukan al-Qur'an. Mereka yang ragu terhadap al-Qur'an sering mempertanyakan, mengapa kisah-kisah dalam al-Qur'an tidak disusun secara kronologis dan sistematis sehingga lebih mudah dipahami? Karena hal itu tersebut menurut mereka dipandang tidak efektif dan efisien. ${ }^{23}$

Sejak dahulu sampai sekarang, telah berlalu empat belas abad, kisah-kisah al-Qur'an yang diungkapkan dalam bahasa Arab itu masih up dated, mendapat tempat dan hidup di hati umat, padahal bahasa-bahasa lain telah banyak yang masuk museum, dan tidak terpakai lagi dalam berkomunikasi seperti bahasa Ibrani, Latin dan lain-lain ${ }^{24}$ Cerita-cerita dalam al-Qur'an bukanlah suatu gubahan yang bernila sastera saja, baik gaya bahasa maupun cara menggambarkan peristiwa-peristiwa, tetapi merupakan suatu media untuk mewujudkan tujuan yang asli. Kisah-kisah dalam al-Qur'an secara umum mempunyai tujuan untuk kebenaran dan

${ }^{23}$ Muhammad Chirjin, al Qur'an dan Ulumul Qur'an (Yogyakarta: Dana Bakti Prima Yasa, 1989), 11.

${ }^{24}$ Nasruddi Baidan, Wawasan Baru Ilmu Tafsir (Yogyakarta: Pustaka Pelajar, 2005), 230. 
semata-mata untuk keagamaan. ${ }^{25}$ Secara garis besar dapat kita simpulkan bahwa, konsentrasi belajar yaitu, pemusatan perhatian, pikiran dan perbuatan pada suatu objek yang sedang dipelajari dan mengabaikan segala hal yang tidak berkaitan dengan objek yang sedang dipelajari. Tujuan dari konsentrasi belajar sendiri adalah agar siswa lebih fokus dan lebih mudah dalam menerima dan menangkap pelajaran yang diberikan oleh guru, sehingga kemampuan berpikir dan pengetahuan siswa pun akan meningkat.

\section{Metode Qișās dalam Pembelajaran di MI Tarbiyatul Akhlaq}

Adanya kisah dalam al-Qur'an menjadi bukti kuat bagi umat manusia bahwa al-Qur'an sangat sesuai dengan kondisi mereka karena sejak kecil sampai dewasa bahkan sampai tua, jarang orang yang tak suka pada kisah, apalagi bila kisah mempunyai tujuan ganda, yakni di samping pengajaran dan pendidikan juga berfungsi sebagai hiburan. Al-Qur'an sebagai kitab hidayah mencakup kedua aspek itu, di samping tujuan yang mulia, juga kisah-kisah tersebut diungkapkan dalam bahasa yang indah dan menarik, sehingga tak ada orang yang bosan membaca dan mendengarnya.

Untuk itu, Bapak M. Ali Mukti, salah seorang guru Pendidikan Agama Islam, dalam upaya mencapai efektivitas yang optimal di dalam kegiatan mengajar siswa MI Tarbiyatul Akhlaq Taman Sidoarjo, penerapan metode qiṣass al-Qur'an dilakukan melalui beberapa tahapantahapan antara lain: Pertama, Perencanaan. Sebelum metode qisash alQur'an qișās al-Qur'an dilaksanakan guru terlebih dahulu mempersiapkan diri untuk mampu menguasai materi secara tepat dan jelas. Hal ini sangat penting karena jika terjadi kekeliruan akan berdampak sangat fatal. Rencana pembelajaran merupakan penuntun dalam mengelola tugas belajar siswa sekaligus mengetahui tingkat keberhasilandalam mengajar. ${ }^{26}$ Kedua, Pelaksanaan. Penerapan metode qisash al-Qur'an dalam pembelajaran menekankan pada kemampuan yang akan menjadi indikator keberhasilan siswa, dengan tahapan-tahapan sebagai berikut: 1) Apersepsi. Guru dapat memberikan apersepsi yang menarik perhatian anak untuk mendengarkan cerita. Misalnya guru menggunakan metode tanya jawab; 2) Penyajian. Guru dalam menyajikan cerita sejarah hendaknya menggunakan gaya bahasa cerita; 3) Korelasi. Menghubungkan peristiwa-peristiwa yang terjadi dalam sejarah dengan

${ }^{25}$ Sayyid Qutb, Seni Penggambaran dalam al Qur'an, Terj. Khadijah Nasution (Yogyakarta: Nur Cahaya, 1981), 138.

${ }^{26}$ Harjanto, Perencanaan Pengajaran (Solo: Renika Cipta, 1996), 6. 
realisasi kehidupan sekarang dan topik-topik pendidikan agama yang lain, ataupun dengan bidang studi lainnyabila ada kesempatan. Di samping itu, guru juga harus mengaitkan sejarah dengan kehidupan modern, guna menggerakkan kecenderungan yang kuat pada diri siswa untuk memiliki semangat kehidupan masyarakat muslim yang sejahtera; 4) Kesimpulan. Guru menyuruh agar siswa-siswa mengulang cerita, dan menanyakan kepada mereka peristiwa-peristiwa, periode demi periode. Setelah itu guru mencatat di papan tulis pokok-pokok kesimpulan dari setiap periode sebagai ihtisar. Dalam hal ini termasuk rangkuman-rangkuman nilai-nilai luhur, moral, dan ajaran-ajaran yang berkesan dengan disertakan sedikit penjelasan tentang keteladanan serta saran-saran yang berguna; 5) Evaluasi. Guru mengadakan diskusi dengan siswa mengenai semua materi yang baru diberikan untuk mengetahui sampai di mana mereka dapat menguasai pelajaran, atau dapat juga merekadisuruh menulis bagian-bagian pelajaran yang mengandung nilai moral, atau mendramatisasikan di depan kelas atau di pentas yang tersedia. ${ }^{27}$

Dalam kaitannya dengan evaluasi pembelajaran, Bapak M. Ali Mukti menambahkan keterangannya berikut ini:

“..Dalam kegiatan evaluasi dapat pula dilakukan dengan menyuruh siswa menuliskan perasaan mereka terhadap tokoh sejarah dan sejauh mana mereka terpengaruh dengan kepribadian dan tingkah laku tokoh tersebut. Dapat juga guru menyuruh beberapa siswa mengulangi cerita tersebut dalam bentuk yang baik, yang dapat merangsang semangat kompetisi positif dikalangan siswa sendiri..."28

Tujuan dikembangkannya metode kisah ditentukan oleh keberhasilan siswa dalam melakukan latihan secara tepat dan lancar yang mampu ditunjukkan oleh siswa secara individual. Oleh karena itu, tes secara individual dan acak sangat diperlukan agar guru dapat mengetahui secara tepat dan mengontrol sejauh mana keberhasilan penerapan metode kisah dalam mencapai tujuan pembelajaran.

Ibu Masning Khumairo', seorang guru Pendidikan Agama Islam, menjelaskan bahwa memang konten di dalam al-Qur'an berisi beberapa kisah yang harus bisa diteladani serta dapat pula dijadikan metode dalam pembelajran.

“..Al-Qur'an sebagai kalam ilahi dan mukjizat agung Nabi Muhammad Saw dua pertiganya berisikan kisah-kisah, sedangkan sepertiganya berisikan tentang aqidah, ibadah dan hukum. Hal tersebut menunjukkan bahwasanya Allah SWT mendidik hamba-hamba-Nya dengan belajar dari sebuah kisah. Di samping itu, naluri manusia lebih suka diberikan kisah

\footnotetext{
${ }^{27}$ M. Ali Mukti, Wawancara, Sidoarjo, 24 September 2019.

${ }^{28}$ M. Ali Mukti, Wawancara, Sidoarjo, 2 Oktober 2019.
}

El-Banat Vol. 9. No.2 (2019) 273 
atau cerita daripada dinasehati. Dari latar belakang itu metode qișās dapat diterapkan ketika anak kehilangan konsentrasi agar fokus terhadap apa yang diajarkan oleh guru..."29

Agar pemakaian metode kisah dapat efektif dan efisien, maka Ibu Masning Khumairo', memaparkan beberapa kiat. Berikut penjelasannya:

“..Kiat dalam menerapkan metode qișās harus dilakukan secara sistematis, di antaranya: 1) Sebelum pelajaran dimulai, hendaknya diawali terlebih dahulu dengan pemberian materi dasar; 2) Metode ini hanya dipakai untuk bahan pelajaran yang bersifat rutin dan otomatis; 3) Siswa diharuskan membaca sebuah kisah; 4) Guru menyempurnakan hasil membaca siswa dengan referansi tambahan; 5) Siswa merefleksi kisah yang dibaca dan penjelasan dari guru... ${ }^{30}$

Berdasarkan keterangan di atas, maka dapat dipahami bahwa efektivitas metode kisah dalam meningkatkan minat belajar siswa siswa akan dapat tercapai manakala proses bimbingan, pengaturan kelompok belajar dan perhatian terhadap kesulitan belajar siswa dilakukan oleh guru secara intensif. Ketepatan dalam merefleksikan kisah sangat pula tergantung kepada keaktifan siswa dalam membaca. Oleh karena itu, kebersamaan guru dan siswa, sikap saling membelajarkan antar siswa akan menentukan keberhasilan siswa dalam mencapai prestasi belajar.

\section{Meningkatkan Konsentrasi Belajar Siswa MI Tarbiyatul Akhlaq melalui Metode Qisās al Qur'an}

Banyaknya metode pendidikan yang ditawarkan para ahli sebagaimana dijumpai dalam buku-buku pendidikan adalah lebih merupakan usaha untuk mempermudah pemahaman siswa atas materi pelajaran yang disampaikan sesuai dengan perkembangan jiwanya. Dalam tugas ini penulis mencoba menganalisis, mendalami dan meneliti metode-metode al-Qur'an dalam menarik perhatian manusia untuk berinteraksi dengannya. Di antara metode al-Qur'an yang mempunyai pengaruh dalam menarik perhatian manusia ialah dengan qishah (kisah), fawatih al-Suwar (ayat-ayat pembuka surat) dan ayat kauniyah (ayat-ayat alam semesta). ${ }^{31}$ Sehingga dalam penelitian ini, penulis tertarik untuk meneliti metode al-Qur'an khususnya metode kisahnya yang diterapkan

${ }^{29}$ Masning Khumairo', Wawancara, Sidoarjo, 29 September 2019.

${ }^{30}$ Masning Khumairo', Wawancara, Sidoarjo, 9 Oktober 2019.

${ }^{31}$ Manna' Al-Qaththan, Pengantar Studi Ilmu Al-Qur'an, Terj. Aunur Rafiq ElMazni (Jakarta: Pustaka Al-Kautsar, 2004), 386. 
dalam dunia pendidikan, terutama dalam upaya untuk mengurangi ketidakkonsentrasian siswa dalam kegiatan belajar mengajar.

“..Dalam menerapkan metode qiṣās, guru harus mendidik dengan mengandalkan bahasa, baik lisan maupun tertulis dengan menyampaikan pesan dari sumber pokok sumber ajaran islam, yakni Al-Qur'an dan Hadits. Dengan metode qișās, guru menyampaikan materi pelajaran dengan menceritakan secara kronologis tentang bagaimana terjadinya sesuatu hal, yang menuturkan perbuatan, pengalaman atau penderitaan orang lain baik yang sebenarnya terjadi ataupun hanya rekaan saja.."32

Metode kisah yang disampaikan di MI Tarbiyatul Akhlaq merupakan salah satu pendidikan yang terbaik, sebab kisah itu mampu menyentuh jiwa jika didasarkan oleh ketulusan hati yang mandalam. Metode kisah adalah pendidikan dengan membacakan sebuah cerita yang mengandung pelajaran baik. Dengan metode ini, peserta didik di sekolah ini dapat menyimak kisah-kisah yang diceritakan oleh guru, kemudian mengambil pelajaran dari kisah tersebut. Karakteristik kisah yang disebutkan dalam Al-Qur'an yakni kisah dalam Al-Qur'an tidak diceritakan secara berurutan dan panjang lebar berarti diceritakan secara ringkas, namun terkadang atau bahkan banyak diceritakan secara panjang lebar. Sebuah kisah terkadang berulang-ulang diceritakan dalam AlQur'an dan dikemukakan dalam berbagai bentuk yang berbeda-beda.

“..Kisah Nabi Yusuf merupakan salah satu kisah yang ditulis dalam AlQur'an. Kisah Nabi Yusuf ini menjadi kisah yang sangat disenangi siswa di MI Tarbiyatul Akhlaq. Siswa bersemangat mendengarkan kisah Nabi Yusuf dikarenakan teladan Beliau. Dan saya sebagai guru juga secara sistematis menyampaikannya karena kisah ini ada dalam satu surat, yakni surat Yusuf. Kisah ini merupakan kisah yang tidak boleh terlewatkan untuk dijadikan sumber materi pembelajaran...”33

Deskripsi Masning Khumairo' tersebut selarah dengan apa yang disampaikan Quraih Shihab dalam tafsir Misbahnya. Menurut Shihab, Q.S. Yusuf dikatakan sebagai ahsan al-qashash (sebaik-baik kisah), karena di samping kandungannya yang demikian kaya dengan ibrah, tuntunan dan hikmah, kisah ini kaya pula akan gambaran yang sungguh hidup melukiskan gejolak hati pemuda, rayuan wanita, kesabaran, kepedihan dan kasih sayang ayah. Kisah ini juga mengandung imajenasi,

\footnotetext{
${ }^{32}$ M. Ali Mukti, Wawancara, Sidoarjo, 11 Oktober 2019.

${ }^{33}$ Masning Khumairo', Wawancara, Sidoarjo, 17 Oktober 2019.

El-Banat Vol. 9. No.2 (2019) 275
} 
bahkan memberi aneka informasi tersurat dan tersirat tentang sejarah masa silam. ${ }^{34}$

Tiga ayat pertama dalam surat Yusuf merupakan pengantar kisah yang terdiri dari beberapa episode. Episode pertama tentang mimipi seorang anak, episode kedua tentang Yusuf disingkirkan saudarasaudaranya, selanjutnya Yusuf dijual kepada orang Mesir, rayuan istri orang, jamuan makan tak terlupakan, dalam penjara, mimpi raja dan kebebasan Yusuf, Yusuf menjadi pejabat pemerintah, pertemuan dengan keluarga, dan yang terakhir bab ke sepuluh tentang i'tibar dari kisah nabi Yusuf as.

“..Di antara pelajaran yang dapat diambil dari QS Yusuf, di antaranya adalah kecemburuan dapat mengakibatkan seseorang membuat tipu daya dan bahkan pembunuhan, jadi kita tidak boleh saling iri. Sesama saudara harus saling menyayangi dan mengasihi. Tidak boleh berbohong, dan lain sebagainya. Dari pemberian kisah ini kepada siswa, diharapkan siswa mampu mengambil pelajaran yang ada pada ayat ini. Serta dapat mengaplikasikannya dalam kehidupan sehari-hari..." ${ }^{35}$

Kegiatan belajar mengajar di dalam kelas tidak akan pernah lepas dari adanya permasalahan. Permasalahan-permasalahan yang terjadi menjadikan hambatan yang harus senantiasa dicarikan solusi-solusinya. Di antara banyaknya permasalahan yang ada dalam kegiatan belajar mengajar, yang menjadi objek dalam kajian ini ialah masalah ketidakkonsentrasian siswa dalam kegiatan belajar. Masalah konsentrasi pada siswa di MI Tarbiyatul Aklak dapat diindikasikan bila perhatian mereka mudah pecah dan teralih. Siswa mengalami kesulitan untuk fokus dalam menyimak suatu hal. Hal inilah yang membuat siswa kerap kali kesulitan menyelesaikan satu masalah yang terjadi padanya. Penyebab kurangnya konsentrasi siswa saat pembelajaran berlangsung yaitu faktor eksternal, faktor internal, dan faktor psikologis. Faktor eksternal meliputi faktor lingkungan dan pola pengasuhan. Sedangkan faktor internal merupakan faktor yang berasal dari dalam diri siswa itu sendiri. Dan yang terakhir faktor psikologis, anak yang mempunyai tekanan tingkat konsentrasinya berbeda dengan anak yang tidak mempunyai tekanan apapun.

“..Banyak sekali penyebab siswa di MI Tarbiyatul Akhlaq hilang dan kurang konsentrasi ketika kegiatan belajar mengajar berlangsung, di antaranya: 1) Ada teman yang mengajak bermain atau berbincang-

${ }^{34}$ Quraish Shihab, Tafsir Al-Misbah Volume. 2 (Jakarta: Lentera Hati, 2005), 389.

${ }^{35}$ Masning Khumairo', Wawancara, Sidoarjo, 25 Oktober 2019. 
bincang; 2) Timbulnya rasa kantuk/mengantuk yang tidak tertahankan; 3) Tubuh merasa kecapekan dan kelelahan; 4) Penat dan bosan dengan materi pelajaran dan metode pembelajaran; 5) Masuk ke dalam bermacam-macam lamunan; 6) Siswa kelas lain pulang atau keluar kelas..."36

Ketika siswa mudah teralihkan dengan kondisi lain di sekitarnya, hal ini wajar, karena mereka sedang dalam proses belajar untuk berpikir dan menganalisa sebab dan akibat. Hal ini mungkin nampak biasa dari kacamata orang dewasa, namun ini merupakan hal yang indah untuk mereka. Dan hal inilah yang menyebabkan siswa cenderung terganggu dengan hal-hal atau kejadian yang terjadi di sekitar mereka. Hanya saja, konsentrasi siswa yang terus-terusan terganggu, tidak dapat dibiarkan begitu saja. Apalagi ketika menghadapi musim ujian, di mana konsentrasi dan daya ingat anak dituntut untuk sebisa mungkin dioptimalkan. Selain itu, proses belajarpun patut dilakukan secara intensif agar siswa mendapat hasil yang diinginkan. Salah satu cara yang dapat dilakukan yakni memilih metode yang tepat.

"..Metode yang tepat bagi anak kurang konsentrasi ialah salah satunya metode qișass. Anak kurang konsentrasi perhatiaanya mudah teralihkan dengan kondisi disekitarnya, maka saya mencari metode yang dengan cepat dapat menarik perhatian siswa kembali, yakni metode qișās. Menurut saya, cerita mempunyai daya tarik yang menyentuh perasaan dan Islam menjadikan sifat alamiyah manusia untuk senang terhadap cerita dan menyadari pengaruhnya yang besar terhadap perasaan. Selain qiṣass Al-Qur'an adalah kalam dari Allah, qiṣass Al-Qur'an juga sarat akan hikmah..."37

Hikmah dari kisah-kisah yang diceritakan dalam al Quran, di antaranya yang paling penting adalah: Pertama, agar kita berfikir/merefleksi. Dalam kisah-kisah al Quran terdapat hikmah bagi orang-orang yang berfikir. Mengambil hikmah dan pesan dari kondisi umat-umat sebelumnya. Jika mereka adalah orang-orang yang binasa, maka umat ini pun perlu diberitahu dan diminta waspada terhadap apa yang membuat umat-umat terdahulu binasa. Jika mereka termasuk orangorang yang sukses, maka umat ini pun perlu mengambil pelajaran dengan meniti jejak kesuksesan mereka. Kedua, Mengenal bagaimana kemampuan Allah memberikan berbagai macam hukuman kepada orangorang yang menyimpang, sesuai dengan hikmah yang telah ditetapkanNya. Ketiga, mengenal penegakkan hujjah kepada manusia

\footnotetext{
${ }^{36}$ M. Ali Mukti, Wawancara, Sidoarjo, 25 Oktober 2019.

${ }^{37}$ M. Ali Mukti, Wawancara, Sidoarjo, 1 November 2019.
}

El-Banat Vol. 9. No.2 (2019) 277 
dengan diutusnya para Rasul, dan diturunkannya kitab-kitab. Mengenal bagaimana para umat terdahulu menghadapi Rasul mereka, apa yang terjadi ketika mereka ingkar kepada para Rasul dan apa yang terjadi ketika mereka menerima seruan para Rasul. ${ }^{38}$

Cerita atau kisah yang disampaikan dengan baik, akan lebih menarik minat anak didik di MI Tarbiyaul Akhlak. Metode kisah dapat mengembalikan konsentrasi siswa dengan baik. Cerita khususnya efektif untuk mempengaruhi cara berfikir dan berperilaku anak. Hal ini tidak saja karena mereka senang mendengarkan atau dibacakan secara berulangulang, tetapi juga disebabkan oleh hakikat cerita itu sendiri yang mempunyai hubungan erat dengan permasalahan emosi lewat karakter yang ditampilkan oleh para tokoh dalam cerita tersebut. Di samping itu, kesesuaian cerita-cerita yang mengandung nilai-nilai keteladanan dapat dijadikan dasar untuk mengajar mereka tentang kecakapan-kecakapan emosional. Melalui cerita-cerita yang dikisahkan tersebut, kecakapankecakapan yang berkaitan dengan kecerdasan emosional dapat ditanamkan kepada anak didik di MI Tarbiyatul Akhlaq secara teliti dan terancang.

Dengan demikian, penulis menganalisis bahwa kisah merupakan refleksi kehidupan nyata, sehingga memiliki daya tarik tersendiri bagi pendengar dan pembacanya, termasuk siswa di MI Tarbiyatul Akhlaq ini. Alur dan tutur cerita memberikan sentuhan emosi yang luar biasa dalam kesehatan anak, sehingga cerita memberikan banyak manfaat bagi perkembangan kepribadidan anak. Memerhatikan emosi siswa dapat membantu mempercepat proses pembelajaran. Memahami emosi mereka dapat membuat pembelajaran lebih berarti dan permanen. Penelitianpenelitian tentang otak semakin menunjukkan adanya hubungan antara keterlibatan emosi serta memori jangka panjang dengan belajar. Perlibatan emosi memengaruhi kagiatan saraf otak. Tanpa keterlibatan emosi, saraf otak berkurang dari yang dibutuhkan untuk merekatkan pelajaran dalam ingatan.

Apabila emosi terlibat dalam pengingatan sebuah informasi, ia akan lebih tercetak dalam ingatan. Di samping dapat menciptakan suasana menyenangkan, bercerita dapat mengundang dan merangsang proses kognisi, khususnya aktifitas berimajinasi, dapat mengembangkan kesiapan dasar bagi perkembangan bahasa, dapat menjadi sarana untuk belajar, serta dapat berfungsi untuk membangun hubungan akrab. Hasil dari penelitian melalui metode observasi yang telah dilakukan, dapat disimpulkan bahwa penerapan metode qisash al-Qur'an dapat dijadikan

${ }^{38}$ Mahmud, Psikologi Pendidikan (Bandung: Pustaka Setia, 2012), 296-297. 
solusi untuk meningkatkan kemampuan menghafal siswa di MI Tarbiyatul Akhlaq Taman Sidoarjo.

\section{Kesimpulan}

Masalah hilangnya konsentrasi siswa merupakan masalah yang kerap sekali dialami oleh siswa MI Tarbiyatul Akhlaq. Siswa tidak memusatkan perhatian sepenuhnya kepada penjelasan maupun apapun yang disampaikan oleh guru di dalam kelas. Hal ini akan sangat mengganggu penyerapan pengetahuan oleh siswa itu sendiri. Oleh karena itu, diperlukan metode yang tepat untuk menangani masalah tersebut. Di antara metode yang tepat adalah metode qiṣās Al-Qur'an. Dalam peneitian ini, diperoleh temuan bahwa qiṣass al Qur'an lebih menarik minat dan perhatian siswa di MI Tarbiyatul Akhlaq. Salah satu kisah yang disenangi siswa di sekolah tersebut adalah kisah nabi Yusuf yang seluruh ceritanya terdapat dalam surat Yusuf. Sebagaimana lazimnya siswa yang sangat senang terhadap cerita, maka dengan menerapkan metode qișās dapat mengembalikan konsentrasi peserta didik. Metode ini efektif untuk mempengaruhi cara berfikir dan berperilaku anak. Karena kisah mempunyai hubungan erat dengan permasalahan emosi lewat karakter yang ditampilkan oleh para tokoh dalam cerita tersebut. Dengan metode qiṣass, guru dapat mengundang dan merangsang proses kognisi siswa, khususnya aktifitas berimajinasi, dapat mengembangkan kesiapan dasar bagi perkembangan bahasa, dapat menjadi sarana untuk belajar, serta dapat berfungsi untuk membangun hubungan akrab di antara siswa dengan lingkungan sosialnya.

\section{Daftar Rujukan}

AR, Zaini Tamin., dan Subaidi. "Implementasi Segregasi Kelas Berbasis Gender dalam Menaggulangi Interaksi Negatif Siswa di SMP AlFalah Ketintang Surabaya". Al Hikmah: Jurnal Studi Keislaman, Vol. 9, No. 1 (2019).

Baidan, Nashruddin. Wawasan Baru Ilmu Tafsir. Yogyakarta: Pustaka Pelajar, 2005

Basri, Hasan. Horizon Al-Qur'an. Jakarta: Balai Kajian Tafsir Al-Qur'an Pase, 2002.

Chirzin, Muhammad. Al-Qur'an dan Ulumul Qur'an. Yogyakarta : Dana Bhakti Prima Yasa, 1989. 
Depag RI, Al-Qur'an dan Terjemahannya. Jakarta: Yayasan Penyelenggaraan Penerjemah / Penafsiran Al-Qur'an Depag, 1975.

Hafidz (al), Ibnu Katsir. Tafsir al-Qur'an al-'Adzim. Mesir: Dar al-Hadits, 2003.

Helmi, Alfian. "Kinerja Guru Dalam Meningkatkan Prestasi Siswa Pada Smp Negeri 2 Babahrot Aceh Barat Daya". Jurnal Admistrasi Pendidikan, Vol.3, No.1, (2015).

Husayn, Muhammad al-Khidr. Balaghat Al_Qur'an. Ali al-Ridha alTunisi, 1971.

Ibrahim, Muhammad Ismail. Mu'jam al-Alfazh waA'lam al-Qur'aniyyat. Dar al-Fikr-al-a'rabi, 1969.

Ilyas, Yunahar. Kuliah Ulumul Quran. Yogyakarta: Itqan Publishing, 2013.

Ishfahani (al), Al-Raghib. al-mufradat fi Gharib al-Qur'an, ed. Muhammad Sayyid Kaylani. Mesir: musthafa al-Bab al-Halab, tt.

Mahmud. Psikologi Pendidikan. Bandung: Pustaka Setia, 2012.

Munawwir, Muhammad Warson. Kamus Al Munawwir. Yogyakarta: UPBIK Pondok Pesantren Krapyak, 1984.

Nawawi. Marah Labid li KasyfiMa'naQur'anin Majid. Semarang: Taha Putra, Semarang. T.t.

Nata, Abuddin. Filsafat Pendidikan Islam. Jakarta: Logos Wacana Ilmu, 1997.

Qattan (al), Manna Khalil. Mahabis fi Ulum al-Qur'an. Mansyurat al-Asr al-Hadis, 1973.

Pengantar Studi Ilmu Al-Qur'an. terj. Aunur Rafiq El-Mazni. Jakarta: Pustaka Al-Kautsar, 2004.

Qutb, Sayyid. Seni Penggambaran dalam Al-Qur'an. Terj. Chadidjah Nasution: Yogyakarta: Nur Cahaya, 1981.

Rapi, Muhammad. "Sertitikasi Guru, Harapan Dan Tantangan Terhadap Guru (Pahlawan Tanpa Tanda Jasa)". Jurnal Harmoni, Vol.2, No.1, (2012).

Roestiyah. Strategi Belajar Mengajar. Jakarta: Bina Aksara, 1985.

Sa'dullah. Cara Cepat Menghafal Alquran. Jakarta: Gema Insani, 2008. 
Shalahuddin, Mahfud. Metodologi Pengajaran Agama. Surabaya: Bina Ilmu, 1987.

Shihab, M. Quraish. al-Mishbah; Pesan, Kesan dan Keserasian alQur'an. Jakarta: Lentera Hati, 2000, Jilid 7. . Membumikan al-Qur'an. Bandung: Mizan, 1994.

2005. . Tafsir Al-Misbah Volume 2. Jakarta: Lentera Hati,

Sudarsana, I Ketut. "Pemikiran Tokoh Pendidikan Dalam Buku Lifelong Learning: Policies, Practices, And Programs (Perspektif Peningkatan Mutu Pendidikan di Indonesia)". Jurnal Penjaminan Mutu, Vol.2, No.2, (2016). 